\title{
Radical changes proposed to the law of corruption
}

\section{by Stephen Silber QC}

The Government is considering proposals from the Law Commission for changes to the law of corruption, which at present has many defects, not least because it is drawn from a multiplicity of sources. Stephen Silber outlines the background to the Commission's views.

$\mathrm{T}$ he Law Commission decided to look at the law of corruption in response to calls from two important committees - the Salmon Commission and the Committee on Standards in Public Life - for a review of this branch of the law. These calls were not surprising as there are many defects in the present law. It is, for example, drawn from a multiplicity of sources, including many overlapping common lav offences and at least eleven statutes.

The problems are illustrated by the uncertainty on the important issue of the precise mental condition that has to be proved before a person can be found guilty of corruption. At common law, corruption has been defined as the receiving or offering of any undue reward from a person, in order to influence his behaviour in office and to incline him 'to act contrary to the known rules of honesty and integrity' (Russell on Crime, 12th ed. (1964) p. 381). It is difficult to be sure what mens rea is covered and similar problems arise with the statutory provisions which use the word 'corruptly' but it has been rightly pointed out that the authorities on its meaning are in 'impressive disarray'. The problem is that the majority views in the leading case say that 'corruptly' means 'to be purposely doing an act which the law forbids as intending to corrupt' (Cooper v Slade (1857) 6 HL Case 746, 773 per Wills J).

There are other problems with the present law because it is dependent on a distinction between public and non-public bodies. There is great uncertainty as to what constitutes a public body, especially as many former public bodies have now been privatised and it is unclear which of them, if any, can still be regarded as public bodies.

\section{THE COURSE OF THE PROJECT}

As usual, the Law Commission consulted with a number of interested parties before producing its consultation paper (Corruption (1997), Consultation Paper No. 145). After its publication in March 1997 we allowed a period of more than three months for responses.

We received a large number of thoughtful and useful responses from many with an interest in or knowledge of the matters covered by the paper. In the light of the responses, we formulated our policy and published our report in March 1998 (Legislating the Criminal Code: Corruption (1998) Law Com 248), with a draft bill.

\section{OUR PROPOSED NEW OFFENCES}

person being encouraged to act in breach of duty by means of a reward. We began our analysis of corruption in terms of an 'agent' being tempted by bribery to betray the trust owed to his or her principal, using the concept of 'agent' in a broad sense of someone who has agreed to perform functions for another person - the agent's 'principal'. We then extended the analysis to include those who have been entrusted to perform a function, not for an identifiable principal but for the public, whether the public of the UK or elsewhere. Significantly, this would enable the UK to comply with the Organisation for Economic Co-operation and Development Convention.

\section{RECOMMENDATIONS}

Our recommendations are to replace the existing common and statutory law of corruption with a modern statute creating four offences:

- corruptly conferring, or offering or agreeing to confer, an advantage;

- corruptly obtaining, soliciting or agreeing to obtain an advantage;

- corrupt performance by an agent of his or her functions as an agent

- receipt by an agent of a benefit which consists of, or is derived from, an advantage which the agent knows or believes to have been corruptly obtained.

The third and fourth of these offences represent a strengthening of the law. At present an agent commits an offence by accepting a corrupt bribe or reward. This seems illogical. What makes bribery wrong is that it tempts an agent to betray his or her principal's trust; yet, while the acceptance of the bribe is an offence, the betrayal itself is not. At present, prosecutions sometimes fail because there is evidence that an agent acted in breach of his or her duty, but not that a bribe or reward was paid or even agreed. Under our recommendations, it would be sufficient to prove that the agent's conduct was motivated by the hope of a corrupt reward, whether or not there was any agreement to that effect.

Again, it is not clear at present whether an agent commits an offence by accepting part of a bribe paid to a third party, in return for favour to be shown by the agent. Under our recommendations this would be an offence.

\section{THE 'CORRUPTLY' CONCEPT}

Central to all these offences is the concept of doing something 
corruptly. This word is used in the existing legislation but is not defined and, as I have shown, its precise meaning is unclear. We believe that it should be defined and have therefore attempted to analyse what it means. Our conclusion is that the essence of corruption lies in the influencing of an 'agent' (that is, a person who has agreed to perform functions for another person - the agent's 'principal' or for the public) to perform those functions in a certain way; and to do so in return (or at least primarily in return) for conferring of an advantage on the agent or a third party. Thus we recommend that a person who confers an advantage should be regarded as doing so corruptly if he or she intends a person, in performing his or her functions as an agent, to do an act or make an omission, and he or she believes that, if that person did so, it would probably be primarily in return for the conferring of the advantage.

The concept of corruption that we recommended in the other offences would build upon the concept of corruptly conferring an advantage. For example, we recommended that a person who obtains an advantage should be regarded as obtaining it corruptly if he or she knows or believes that the person conferring it confers it corruptly, and he or she either requests it or at least consents to obtaining it.

Read literally, these definitions would include an agent's remuneration by his or her principal (or on behalf of the public), and we therefore recommend an express exception for such remuneration. We also recommend a further exception for the case where the agent's principal knows all the material circumstances and consents to what is done.

Our consultees agreed with our provisional view that there should be no distinction between public and non-public bodies. It was agreed that it is not desirable to have different standards and we therefore recommend the abolition of the distinction.

\section{ANCILLARY MATTERS}

The investigation of corruption is an integral part in successfully proving corruption. We considered whether the powers of the police should be extended, either to those enjoyed by the Serious Fraud Office or in some other way, in cases of corruption. Whilst we accept that an anomaly arises in circumstances where a case falls within the remit of the SFO but, for whatever reason, is investigated by the police, we concluded that extending the powers of the police would create a greater anomaly between cases of corruption and other cases of fraud. Additionally, we considered that an extension of police powers might be vulnerable to challenge under art. 6 of the European Convention on Human Rights. We therefore did not recommend that the investigative powers of the police should be extended in the case of corruption.

We carefully considered the issue of territorial jurisdiction and the new offences of corruption since, as we pointed out, corruption has an increasing international element. We recommended that the new offences of corruption should be included in the list of Group A offences for the purposes of Part I of the Criminal Justice Act 1993, which extends the jurisdiction of the English courts over offences of fraud and dishonesty committed abroad.

We recommended that prosecutions for the new offence should not require the consent of either the Law Officers or the Director of Public Prosecutions. Although we took the view that corruption is a serious offence we do not think that it is right to say that all instances of corrupt behaviour are sufficiently serious to require trial on indictment. We recommended, therefore, that the new offences should be triable either way.

In the consultation paper, we asked for views on whether the procurement of a breach of duty by deception or threats should be criminal. We conclude that, although the present law may not deal adequately with such circumstances, they should not be caught by the law of corruption.

\section{Stephen Silber QC}

Law Commissioner

\section{What makes a good lawyer an expert?}

\section{Legal information as it happens}

New Law Publishing

- Proactive Daily Digest Service

- Selects, edits and delivers on the same day as judgment

- Cross-referenced and indexed database of judgments

Fourth Floor, Quality House, Quality Court, Chancery Lane, London WC2A IHP Tel: 01714055434 Fax: 01714055693 E-Mail: info@newlawonline.com 